\title{
A case for examining pre-service teacher preparation for inquiry teaching science with technology
}

\author{
Chris T. Shively a and Randy Yerrick ${ }^{\mathrm{b} *}$ \\ ${ }^{a}$ Department of Elementary Education and Reading, The State University of New York, \\ New York, USA; ${ }^{b}$ Department of Learning and Instruction, The State University of New York, \\ Buffalo, New York, USA
}

(Received 13 June 2013; final version received 8 September 2014)

Inquiry has been the framework for guiding reform-based science instruction. All too often, the role of technology is treated tacitly without contributions to this framework. This case study examines a collection of pre-service teachers enrolling in two educational technology courses and the role these experiences play in promoting inquiry teaching. Interviews, field notes, surveys, reflective digital narratives and student-generated exhibits served as the data informing the analysis of inquiry experiences which shaped the enacted lessons of science teachers. Implications for research and practices are discussed.

Keywords: teacher reflection; science education; technology

Before I did not know of any ways for them to do science except for the crappy cookbook, stupid labs that they do, that the State mandates. They [Cooperating Teachers] feel they're [Students] are not going to learn unless they tell them everything ... I don't know, when I was learning science all through school and when I was teaching science in my student teaching, it was lecturing out of the book. I think that it's just a product of how we have all been taught our entire life. (Holly, Interview)

\section{Introduction}

Holly is an aspiring science teacher who had just encountered inquiry science teaching for the first time in graduate school. Despite living through an era of multiple science education reforms which called for students of all grade levels to use scientific inquiry and appropriate tools, she professed to have never seen it in her entire K-20 (Kindergarten - Graduate School) experience. Instead she recounted learning experiences where she sat through lecture after lecture and test after test that covered abstract concepts with an occasional state-mandated 'cookbook' lab thrown in.

During the first month of an elective science education graduate course, Holly and her classmates investigated the principles of heat transfer in a problem-based learning environment using temperature probes, computers and digital microscopes. The guided inquiry approach provided experiences for novice teachers to learn what it means to learn science by inquiry. The National Science Education Standards (NSES) first announced in 1996 calls for students to learn to collect, analyse and

*Corresponding author. Email: ryerrick@buffalo.edu 


\section{C.T. Shively and R. Yerrick}

discuss their own data using scientific tools. These NSES have now gone through a complete revision and are now being replaced by the Next Generation Science Standards (Schweingruber et al. 2012) These reform standards, backed by decades of research, argue students do science when they are engaged in asking questions, planning and conducting investigations, using appropriate tools and techniques to gather data, thinking critically and logically about relationships between evidence and explanations, constructing and analysing alternative explanations, and communicating scientific arguments. The vision prescribed by these documents contends when students learn with inquiry, they are practicing what scientists think, say and do in their regular work - using cultural tools for like microscopes, computers and probeware to mediate their learning, speak, thinking and acting.

Yet, according to Holly and her peers, guided inquiry lessons were an anomaly. Were Holly and her classmates oblivious to the efforts of their former teachers or had school practices continued their traditional course, unabated from the numerous calls (AAAS 1989; NGSS Lead States 2013) for science teaching reform? As preservice teachers (PSTs), they had all been placed in two student teaching assignments, and Lortie estimates PSTs take in over '... 13,000 hours of direct contact with classroom teachers' (Lortie 1975, p. 61) in their K-20 preparation leading to their first science teaching job. We ask, 'How could this bright, articulate Honors Biology student profess ignorance that she was unaware of any another way to teach?' It is into this resilient context that we place technology into the hands of teachers and assume change will naturally occur. In the following sections we will elaborate on the complexities of teacher change and the promising potential for technology to facilitate what our national science education reforms demand.

\section{Inquiry in science education}

Inquiry has been the framework for guiding reform-based science instruction since the writings of John Dewey (Barrow 2006). Olson and Loucks-Horsley (2000) argued that students at all grade levels and in every domain of science should have the opportunity to think and act in ways associated with inquiry. Because the implementation of inquiry can look very different in science classrooms (Mintzes et al. 2000), it is important to define an inquiry framework. Windschitl (2003) reviewed the work of science educators promoting and studying inquiry teaching and developed an 'inquiry continua' (p. 114) or levels of inquiry that provide structure to this construct. This continuum identifies increasing levels of complexity and student independence in constructing meaning from Confirmation Exercises to Open Inquiry. It is at this highest level which places the full responsibility of learning on the student where inquiry tools bring unobservable evidence to the fore, enable abstraction and analysis, and engage students in the active co-construction of scientific knowledge and interpretation.

The arrival and rapid evolution of so many varieties of tools (e.g., computers, tablets, simulations, peripherals) have convoluted the landscape for science teachers because there has been gross neglect for professional development (Cuban 2001; Oppenheimer 2004) and a variety of contextual influences on implementation so that teachers are not sure where to use tools in the curriculum, what tools to use and how to use them (McCrory 2008; Waight and Abd-El-Khalick 2011). When introducing technology into science lessons, teachers and teacher educators alike confess their lack of knowledge, their needs and their interest in learning more to teach technology better (Settlage, Odom, and Pedersen 2004). 
There is very little support to develop the necessary pedagogical skills and knowledge to implement them effectively (Cuban 2001; Harris, Mishra, and Koehler 2009; Oppenheimer 2004). Though the obstacles for teaching science inquiry through technology have been thoroughly explored elsewhere (Berger et al. 1994; Ellington 1993; Jonassen 1996; Lawrenz 1993) suffice to say that, on the whole, schools deter innovative technological and pedagogical choices for teaching inquiry (Cuban 2001; Waight, Chiu, and Whitford 2014).

\section{Technology's role in science inquiry teaching}

There has been a widespread debate among researchers as to the teaching value of technological tools such as computers (Cordes and Miller 2000; Cuban 2001; Mehan 1989; Mistler-Jackson and Songer 2000; Oppenheimer 2004; Williams and Linn 2002) and effectiveness, which dates back to the first insertion of tools into schools (Cuban 1986). Researchers argue it is unlikely that PSTs learned science using technology (Niess 2008) and very likely that their pedagogical and content knowledge of science is rudimentary (Angeli and Valenides 2008). Despite these deficiencies in technological, pedagogical and content knowledge, science educators can improve a pre-service science teacher's knowledge base by providing them with multiple opportunities to practice teaching with technology without formally evaluating them. Angeli (2005) recommends that PSTs consider using technology as '... a learning tool for enhancing their teaching practices and not just a delivery vehicle for supporting old ones' (p. 385). PSTs need to be able to take risks during their teaching practice with tools they did not learn with or watch their teachers use.

Some authors have characterised learning to teach with technology as a strongly connected web of domains that prevents it from being treated as simply imparting technological knowledge. Building off the foundations of Shulman (1986), the framework of Technological Pedagogical Content Knowledge (TPCK) posits that many areas of knowledge influence a teachers selection, implementation and evaluation of teaching with technology (Mishra and Koehler 2006). They referred to teaching as 'a highly complicated form of problem-seeking and problem-solving that derives from flexible and integrated bases of knowledge' (p. 3). These bases of knowledge serve as theoretical frameworks for discussing pre-service teacher education and the requisite knowledge universities can impart or foster to prepare excellent teachers. Authors argue that neither pedagogical, content, nor technical knowledge can be omitted from any discussion of effective teaching (Angeli and Valanides 2008; Koehler and Mishra 2005) and all are needed to facilitate student learning.

McCrory (2008) has provided one framework through which science educators and PSTs can view effective integration of technology. His conceptual framework encompassed three basic realms of technology implementation: (1) Where teachers should use technology in the curriculum, (2) What technology teachers should use and (3) How teachers should teach with technology. McCrory (2008) proposed that PSTs use technology in parts of the curriculum that are hard to teach and in places where technology is integral to learning about science.

It was from this orientation that we examined two educational technology course electives offered to science teacher candidates and to explored which experiences added to their proficiency to teach science with technology supporting inquiry teaching. We examined the technological, content and pedagogical knowledge (Mishra and Koehler 2006) of pre-service science teachers prior to graduating with a secondary 


\section{C.T. Shively and R. Yerrick}

science teaching degree. The PSTs in this study all entered school during when the NSES (NRC 1996) were released and entered high school at a time when schools focused on meeting the requirements of No Child Left Behind [NCLB] (2002). Within this context we asked the following research questions,

- What academic experiences influence PSTs interpretation inquiry teaching with technology tools?

- What components of education technology courses, if any, contributed to PSTs notions of inquiry science teaching?

\section{Methodology}

A bounded, case study approach (Creswell 2007) was used to explore PSTs' understandings of how to teach science using inquiry and technology. Twelve PST graduate students who had completed a Bachelor's degree in science and were finishing a Master's Degree in science education were asked to participate in learning content through inquiry using specific teaching tools like probeware, software, digital microscopes, laptops, digital video cameras and other co-constructive tools. Enrolled in an elective educational technology course, they were also asked to prepare and teach lessons using these tools in local middle school classrooms during the semester. These lessons would be recorded, and PSTs were expected to compile a portfolio or exhibit demonstrating their use of the tool in context and their learning about teaching with technology.

Students modelled their lessons after those they had participated in their elective course. Guided inquiry lessons (Windschitl 2003) introduced students to scientific tools that enabled them to collect their own data to analyse and use as evidence to support their findings, which they eventually shared with their peers. Following each example lesson PSTs deconstructed the lessons to define the role technology had played during instruction.

\section{Data collection and instruction}

Our research design was framed by the concept of 'research as praxis' (Britzman 1991; Lather 1996), which has at its core an assumption that research can and should affect teachers' actual practice. Therefore, our collection of artefacts and methods for conducting interviews were influenced by our philosophical stance as teacher educators that, if novice teachers were going to be successful in teaching science, they would likely need to understand both philosophical and practical implications of technology choices on children's thinking, their planning and their lesson implementation.

Multiple sources of data were collected from each of the PSTs. These sources included: formal interviews with each PST, a 41-question survey, collected lesson plans, and the PSTs' own video reflections, constructed to report the success of their devised lessons. A digitally recorded interview was conducted with each of the PSTs on and off campus and later transcribed. The interview covered six areas of pedagogical, content and disciplinary knowledge. In addition, a 41-question survey using a Likert scale, was administered anonymously to the PSTs to avoid the experimenter 
effect (Bracht and Glass 1968) regarding teaching science with inquiry and technology. Embedded in the survey were 17 open-ended questions, which enabled the PSTs to expand on their experiences, using technology and inquiry. While there was no statistical significance for a such a small survey sample, the survey directed us to the PSTs definitions for central notions like inquiry and their related content, technological and pedagogical choices.

We collected their personal video-recorded reflections explicating their individual learning outcomes and conducted final exit interviews to corroborate the claims PSTs made regarding their design and implementation of technology in their teaching. The use of video to capture instruction and PSTs' was a specific measure in our design to both elucidate the explicit use as well as provide meaning for the intentions of implementation as in other studies (Borko et al. 2008). Video enabled teachers reflecting on their teaching to conduct repeated viewing which fostered connections between the pedagogy, ideas about student thinking and the use of the technology simultaneously. The PSTs collected video of their lessons, edited the video to a final product and used the remaining clips to tell a narrative about their science lesson. They followed the same process when constructing a video of their interviews with their students and mentor teacher.

\section{Data analysis}

Data Analysis was completed in three phases including initial coding, axial coding and the development of case studies from narrative analysis. Following initial coding of the interviews using selective coding techniques (Corbin \& Strauss, 2008) categories were developed describing themes observable across the data set. These categories included such themes as use of technology, learning science, pedagogical choices and others which allowed researchers to break down interview and video data and conceptualise it into manageable parts.

After using open coding procedures to produce categories, axial codes were generated to reveal relationships between subcategories within the categories. Researchers used these axial codes to see patterns in the data which eventually led to the assertions made in the findings which gave meaning to the subsequent case studies (Creswell 2007). These quotes were used to support or refute assertions and gave clearer refinement to the assertions clearly articulated across the data and led to finding explicit differences between teachers.

It was important to consider what PSTs thought was prominent about their use of technology and how they chose to represent their teaching and learning actions (Wertsch 2000; Richardson 1996). Narrative analysis was used to identify the pedagogically mediated actions PSTs chose to discuss about their use of technology. It served as a sociocultural lens to PSTs actions and intentions. Though observation studies, surveys and other methodological approaches may report an outsider's view to technology practices, narratives allow for the interpretation of mediated actions during the teaching of their lessons (Riessman 1993). The interview questions and video reflections provided the PSTs with the opportunity to choose what reconstructions participants make meaningful. This qualitative analysis technique enabled researchers to interpret intentions, goals and values from the PSTs' constructive responses of past learning and teaching. 


\section{C.T. Shively and R. Yerrick}

\section{Findings and discussion}

\section{Assertion \#1: Prior learning experiences and teaching placements proved insufficient preparation for effectively using technology to teach inquiry science lessons}

\section{Prior learning experiences}

PSTs were asked if they believed inquiry was important to the process of teaching science, all of them agreed. Yet PSTs reported they did not recall using tools like computers, probes, or other inquiry tools in their Kindergarten - College Graduate learning of science. They recalled only listening to lectures, taking notes and completing homework problems and worksheets.

Nicholas: All through my educational career it has been traditional lecture, traditional notes, traditional labs where you're given the lab write up, this is what you do, answer these questions and that's it. (Nicholas, Interview)

To their recollection teachers did not offer them opportunities to ask questions, design their own investigations and collect their own data as recommended by the standards. PSTs described their role as merely answering questions posed by their teachers, following their teacher's directed lab procedures, handing in assigned homework, and preparing for factual chapter quizzes and state-mandated assessments. The traditional labs they completed did not implore modern tools and required them only to observe the phenomena to accompany their memorisation of facts and definitions, correct answers and learning to take tests. The result was a means for coping, such as describing how they copied answers knowing their teacher cared only if the labs demonstrated the right answer turned out correctly.

\section{School placement}

PSTs also noted during their lessons the same behaviours in the middle school students they taught. Middle school students reported to PSTs they 'just write stuff down or copy it from their friends' when they write up a traditional lab. Middle school students were unfamiliar with the kinds of explorations, control over experimental design and classroom interactions PSTs asked them to participate in. It reminded Rick of his own school science experience. Rick reported,

Rick: It was a shift in expectations ... When they [MS students] did a lab report they would just write stuff down or copy it from their friends just to get it on the paper and just to get it done to get a grade.

PSTs also reported their Cooperating Teachers for student teaching required students to take notes during class and follow pre-determined directions and lab procedures. They rarely saw any use of tools beyond the delivery of science notes and facts using PowerPoint ${ }^{\mathrm{TM}}$. The classroom teachers did offer students required them to practice specific process skills, gather pre-determined data using traditional tools like rulers and glass thermometers, and use their data to answer questions related to a single correct answer. PSTs were compelled to cover as much as they could because during their placement as their Cooperating Teachers strongly suggested the content, lessons and pacing guide they should follow. 
Peter: My Cooperating Teacher basically said, 'You will be gone in 6 weeks, but I have them to the end of the year. I want to be sure I don't have to do too much scrambling at the last minute to get my kids ready for the test after you leave ... here are the chapters you should have done by then.'.

Christian: I guess at the beginning of the semester I was really focused on giving them as much stuff as I could, like during the school year. I just wanted to make sure I covered everything. This semester, has taught me that it is not so important to deliver as much as you can because if they're not taking it in it doesn't matter if you delivered it or not.

PSTs expressed intense pressure to cover a great deal of content in very little time during their student teaching, which they felt negated any reform-based teaching including inquiry. The PSTs suggested that they felt compelled to aim for the highstakes material for the end of the year test reinforcing Southerland's and others' claim many teachers believe current reform visions are in conflict with state-mandated curriculum focusing heavily on content coverage (Southerland et al. 2007).

In some cases PSTs were placed in classrooms where the most modern technology was an overhead projector. Students were asked directly, 'Prior to this semester, what technology tools have you used with students'? PSTs often responded like Nicholas with embarrassment, 'I haven't tried much because the schools I student taught in didn't have too much'. In other cases PSTs were placed with classrooms with modern technology however, modelling of tools and expert pedagogy was lacking.

Holly: I was told when I used this room to keep my hands off of everything. I was told it [SmartBoard] was not mine, and it wasn't really even the school's because some grant put it in. It was clear. I was not to use it [computer-SmartBoard] because I hadn't been trained. When I inquired how I could be trained with the administration, I was told by two different people, only district faculty were allowed to be trained ... something about the workshops are full.

Even in the rare cases of student teaching where PSTs had access to some tools, their knowledge was eclipsed by the lack of explicit teacher professional development guiding them in a use of the tool for inquiry. Such placements served to reinforce negative feelings toward their past K-20 learning experiences.

\section{Assertion \#2: Exit PST artefacts demonstrated an increasingly progressive inquiry oriented use of technology tools}

PSTs designed and implemented lessons using inquiry tools, collected videos and students' evidence of learning, and created electronic exhibits to share with their peers. In doing so, PSTs demonstrated many core components of inquiry science teaching in their planning as well as implementation despite their lack of exposure. Artefacts collected from the lessons taught by PSTs reflected a progressive migration from a controlled and guided orientation of inquiry toward a more open inquiry environment (Windschitl 2003) and many of those artefacts demonstrated a central role of technology within the planned lesson. For example, in Nicholas' lesson he asked his students 'What makes us cold'? He gave his students temperature sensors and a laptop computer to examine the effect of wind on warm surfaces. He chose to use temperature probes because his interviews with students revealed wind chill was a difficult concept for his students to conceptualise and led to much misunderstanding when taught via traditional means. So his students captured and shared temperature 


\section{C.T. Shively and R. Yerrick}

data in order to draw conclusions based on data observed at their own lab station and throughout the class.

Nicholas: With thermometers you can't really see much of a difference when trying to test wind chill ... they were actually able to see the difference between the two temperatures [using probes and laptops]. I wanted my students to see that wind chill doesn't affect temperature, it just makes warmer objects cool down to their environmental temperature. I want my focus to be on the kids doing and explaining and more of an inquiry focus. I would have never thought of that before.

When Nicholas interviewed his Cooperating Teacher after the lesson, he described the importance of using technology in this lesson. Even his Cooperating Teacher said,

Cooperating Teacher: It gave my students the opportunity to pay attention to the data more. This put the focus on the important stuff ..., what the data means ....

Holly and Rick also made technological choices for their lesson which helped their students document owl pellet dissections. They chose digital computer linked microscopes, electronic iPhoto ${ }^{\mathrm{TM}}$ books, and concept mapping software for students to infer ecosystems and construct energy webs. They defended their choices by stating,

Holly: Students could get a closer look at the owl pellets than they could with a traditional, hand-held magnifying glass ... and requiring photos helped capture the bones and contents. I now have better tools to use instead of lecture to address different types of learning. I can approach students with different learning styles .... We're having kids actually doing something ... that IS SCIENCE. [Emphasis hers]

In similar ways Peter used $\mathrm{pH}$ sensors to replace the traditional $\mathrm{pH}$ litmus lab prescribed by the State curricular guidelines while Sean and Christian developed an improvement over the state-mandated lab monitoring students' accelerating heart rate. Peter learned to use probes and data in a way that directly addressed some of the naïve thinking student to such an abstract concept like $\mathrm{pH}$. The use of the $\mathrm{pH}$ sensor was instrumental in developing a more conceptual base when labs didn't turn out the right answer. Peter, Sean and Christian each found that concentrating on data through their designed lessons allowed students to 'see' concepts in different ways and succeed.

Peter: In the past, when I know what's supposed to happen and didn't happen. We would make up stuff for the kids and we would give them data and they would graph it, but it's not authentic. (Peter's interview with his CT)

The PSTs selected technology to help their students learn a part of the curriculum that they deemed difficult to understand without the use of tools. The PSTs picked technologies that would collect, organise and transform data so that their students could focus on the science concepts being learned and not on collecting data. PSTs acknowledged that inquiry took longer than handing out data or following traditional labs.

\section{Assertion \#3: PSTs attributed their inquiry practices to choices made surrounding the technology tool}

When asked whether inquiry was important to the process of teaching science, exit surveys demonstrated that all PSTs strongly agreed. Many PSTs recounted during 
their exit interview that they wanted their future students to act more like scientists; they wanted them to be active learners, to do things in science class. Inasmuch, they identified specific goals for their students like collecting data, asking questions, interpreting or analysing their findings which all pointed directly to the role technology played in their plans. These tools used on campus were the same ones taken out to the field where PSTs taught. PSTs reported,

Nicholas: In this class, it was a lot of hands-on. Instead of learning about why we should do something or why it will work, we were shown how to use something .... He showed us how we could easily take a lesson where we followed instructions into making it more student and inquiry oriented like, 'what do you think we should do?', 'what do you want to test out?

Moreover, the PSTs were able to each handle and manipulate the technology, produce learning artefacts to reflect upon, and practice inquiry teaching strategies consistent with a TPCK framework (Koehler and Mishra 2008). Thus, they were provided with a relevant purpose for learning the tool and the expectation that it would be used in their future lessons with children.

Johnny: With this course, with all the tools, it helped me think of ways that I could give it to them so that they could do it themselves .... We used the probeware, which was new to me and is definitely going to be valuable in the classroom .... So, in, doing things the non-traditional way, where students are given a lot more freedom to test things out ... he would teach us a piece of technology and we would use the piece of technology to do something .... We did a lot of things that were helpful in planting in our heads how we would use this in the classroom.

The PSTs were able to learn where, what and how to use technology in a generic science curriculum. Their professor taught them how to take a lesson that required students to follow a set of directions written by the teacher or textbook to verify a science concept, what Windschitl's (2003) called Confirmation Exercises, and transform that same lesson into a higher level of inquiry by simply enabling kids to ask questions and use the proper technology tools.

Holly, Rick and Sean found value in using technology the technology they were learning about for their future careers as science educators which transcended the knowledge of the existence of tools, simple exposure to the tool, or basic operational and technical knowledge of the tool. PSTs were quickly able to identify purposeful uses for a variety of technology tools when used within an inquiry framework like Windschitl (2003).

Rick: But after this class I can really see how important it [using technology] is because there is so much out there that I never even thought could be there. And knowing that it's there and knowing that I could use it in the class successfully is something really important to me because I've always had an idea, I just never had the full idea.

PSTs each recounted how meaningful it was to think about the tool in terms of learning because of the immediate application to the learning of content as well as the expectation that they use it with children in real school contexts lending credence to Koehler and Mishra (2008) claims that technological knowledge is acquired in concert with its pedagogical applications. Through these relevant science learning experiences PSTs co-constructed specific pedagogical and technological knowledge 


\section{C.T. Shively and R. Yerrick}

they could use for teaching. In short, PSTs learned how to give their students the freedom to control their own learning through inquiry practices - all this despite the deficit of both PSTs and middle school students' prior exposure to this kind of educational technology. Holly said it best when she described,

Holly: I walked away from that class using tools I had never heard of before. I did not know probeware existed. It is nice to know you could use something so user friendly with kids.

\section{Discussion and implications}

In this study, the PSTs were provided with probeware, laptop computers, a digital video camera and digital microscopes with expectation that they would use these tools to teach and reflect on their practice with select Cooperating Teachers in environments where pedagogical experimentation was welcomed. Though PSTs professed having not witnessed inquiry tools in their K-16 learning experience, they each were able to define a central moment where they were encountered and changed their practices through their enrolment in a single field-based, technology-rich, reflectiondriven technology course. They used this new knowledge to successfully design and implement a science lesson as teachers with middle and high school students in public school classrooms.

Without the opportunities offered by this elective science course, PSTs would have graduated professing never to have been exposed to such tools, pedagogies or assessment methods. If the role of higher education is to prepare teachers for such visions of science teaching, clearly one course is not enough. However, it should be noted that every student who completed this educational technology course had a successful experience learning to teach using inquiry and intended to practice it more in their next job. We gather from our data that students wished they had been exposed to alternatives earlier and that too much traditional teaching drives students' motivation for learning downwards.

We must ask the question, 'Why haven't calls for inquiry science teaching reform and technological integration into science classrooms taken root?' Several studies demonstrate the strong influence of placements and mentoring of PSTs (Windschitl 2003; Gado, Ferguson, and van t Hooft 2006; Anderson 2002; Lotter, Singer, and Godley, 2009). Other studies suggest the general resilience of schools contexts to change (Sarason 1982). Still other factors researchers argue include professional development, assessment-driven curricula, poor administrative support and a host of other factors. If we are serious about changing science classroom instruction to embrace the latest tools for inquiry, we must strongly attend to more than one of these factors at a time and consider larger decision-making knowledge frameworks like TPCK and others which explore a richer set of data than just technological knowledge.

Reformers, futurists and technological zealots have argued that classrooms will change when this next generation of learners join the ranks of teachers. We disagree. How can they? What knowledge and experiences will they have to draw upon when they become teachers? How long will Holly, Nicholas or Peter resist the barrage of traditional school practices with peers and administration insisting they conform and keep up with the pacing guide? These PSTs are now leaving and entering schools of education with strong perceptions of what it means to be a science teacher during an era when the results of high-stakes tests have a greater influence than ever before. 
Without classroom experiences that enable PSTs the opportunities to teach science with inquiry supported by technology, PSTs can never gain confidence, experience or competence required 'to integrate technology in their classroom practices in more sophisticated ways' (Angeli and Valenides 2008, p. 22). The experiences out in real classrooms contributed to the development of their TPCK that would have clearly been insufficient without such factors as supportive Cooperating Teachers, modelled practices, exemplary tools, creative teaching spaces and facilitated reflections on central literature framing the issues.

Educational technology courses can teach how to use technology but Mishra and Koehler (2006) argue it cannot teach them how to use technology to teach the practice of science without clearly connecting it to requisite pedagogical content knowledge to make sense of the instruction (McCrory 2008). It seems misguided to hold out hope for the next reform vision without supporting PSTs to learn tools, in a content specific environment, with mentors who can observe and advise, as students are encouraged to safely try out new pedagogies and approaches with real children. We have shown it is possible, albeit labour and resource dependent. But since when has anything worthwhile not required significant investment? We believe in the value of the current Next Generation Science Standards and calls for the use of inquiry tools in the classroom and hope beyond hope for the next generation of science teachers and learners get the support they need to make the necessary changes.

\section{References}

Anderson, R. D. (2002) 'Reforming science teaching: what research says about inquiry', Journal of Science Teacher Education, vol. 13, no. 1, pp. 1-12.

Angeli, C. (2005) 'Transforming a teacher education method course through technology: effects on preservice teachers' technology competency', Computers \& Education, vol. 45, no. 4 , pp. $383-398$.

Angeli, C. \& Valanides, N. (2008) 'TPCK in pre-service teacher education: Preparing primary education students to teach with technology', Annual meeting of the American Educational Research Association, New York City, NY. http://punya.educ.msu.edu/presentations/ AERA2008/AngeliValanides_AERA2008.pdf.

Barrow, L. H. (2006) 'A brief history of inquiry: from dewey to standards', Journal of Science Teacher Education, vol. 17, no. 3, p. 265.

Berger, C. F., et al., (1994) 'Research on the uses of technology in science education', Handbook of research on science teaching and learning, pp. 466-490.

Borko, H., Jacobs, J., Eiteljorg, E. \& Pittman, M. E. (2008) 'Video as a tool for fostering productive discussions in mathematics professional development', Teaching and Teacher Education, vol. 24, no. 2, pp. 417-436.

Bracht, G. H. \& Glass, G. V. (1968) 'The external validity of experiments', American Educational Research Journal, vol. 5, no. 4, pp. 437-474.

Britzman, D. (1991) 'Decentering discourses in teacher education: Or, the unleashing of unpopular things', Journal of Education, vol. 173, no. 3, pp. 60-80.

Corbin, J. M. \& Strauss, A. L. (2008) Basics of qualitative research: Techniques and procedures for developing grounded theory, Sage Publications, Inc., Thousand Oaks, CA.

Cordes, C. \& Miller, E. (2000) Fool's gold: A critical look at computers in childhood, Alliance for Childhood, College Park, MD.

Creswell, J. W. (2007) Qualitative inquiry \& research design: Choosing among five approaches, 3rd edn, SAGE Publications, Inc., Los Angeles.

Cuban, L. (1986) Teachers and machines: The classroom use of technology since 1920. Teachers College Pr, New York, NY.

Cuban, L. (2001) Oversold and underused: Computers in the classroom, Harvard University Press, Cambridge, Mass. 


\section{C.T. Shively and R. Yerrick}

Ellington, H. (1993) Handbook of educational technology, Nichols Publishing, East Brunswick, NJ.

Gado, I., Ferguson, R. \& van t Hooft, M. (2006) 'Using handheld-computers and probeware in a science methods course: Preservice teachers' attitudes and self-efficacy', Journal of Technology and Teacher Education, vol. 14, no. 3, p. 501.

Harris, J., Mishra, P. \& Koehler, M. (2009) 'Teachers' technological pedagogical content knowledge and learning activity types: curriculum-based technology integration reframed', Journal of Research on Technology in Education, vol. 41, no. 4, pp. 393-416.

Jonassen, D. H. (1996) Handbook of Research for Educational Communications and Technology. A Project of the Association for Educational Communications and Technology (AECT), Macmillan Library Reference USA, Simon \& Schuster Macmillan, 1633 Broadway, New York, NY 10019.

Koehler, M. J. \& Mishra, P. (2005) 'What happens when teachers design educational technology? The development of technological pedagogical content knowledge', Journal of educational computing research, vol. 32, no. 2, pp. 131-152.

Koehler, M. J. \& Mishra, P. (2008) Introducing tpck, Handbook of Technological Pedagogical Content Knowledge (TPCK) for Educators, pp. 3-29.

Lather, P. (1996) 'Methodology as subversive repetition: Practices toward a feminist double science', in Annual meeting of the American Educational Research Association, New York City, NY. (Vol. 19).

Lawrenz, L. S. E. (1993) User-Friendly Handbook for Project Evaluation: Science, Mathematics, Engineering, and Technology Education, National Science Foundation.

Lortie, D. C. (1975) Schoolteacher, University of Chicago Press, Chicago, IL.

Lotter, C., Singer, J. \& Godley, J. (2009) 'The influence of repeated teaching and reflection on preservice teachers' views of inquiry and nature of science', Journal of Science Teacher Education, vol. 20, no. 6, pp. 553-582.

McCrory, R. (2008) 'Science, technology and teaching: The topic-specific challenges of TPCK in science', in B. Cato (Ed.), The handbook of technological pedagogical content knowledge ( TPCK) for educators, pp. 193-206, Lawrence Erlbaum.

Mehan, H. (1989) 'Microcomputers in classrooms: educational technology or social practice'? Anthropology \& Education Quarterly, vol. 20, no. 1, pp. 4-22.

Mintzes, J. J., Wandersee, J. H., Novak, J. D. \& Mintzes, J. J. T. (2000) Assessing science understanding, Academic Press, San Diego.

Mishra, P. \& Koehler, M. J. (2006) 'Technological pedagogical content knowledge: a framework for teacher knowledge', Teachers College Record, vol. 108, no. 6, pp. 1017-1054.

Mistler-Jackson, M. \& Songer, N. B. (2000) 'Student motivation and internet technology: are students empowered to learn science'? Journal of Research in Science Teaching, vol. 37, no. 5 , pp. $459-479$.

National Research Council (NRC). (1996) National Science Education Standards, National Academy Press, Washington, DC.

NGSS Lead States. (2013) Next generation science standards: for states, by states, The National Academies Press, Washington, DC.

Niess, M. L. (2008) Guiding preservice teachers in developing TPCK, In B. Cato (Ed.), The handbook of Technological Pedagogical Content Knowledge (TPCK) for Educators, pp. 193-206. Lawrence Erlbaum.

No Child Left Behind (NCLB). (2002) Act of 2001, Pub. L. No. 107-110, § 115, Stat. 1425.

Olson, S. \& Loucks-Horsley, S. (2000) Inquiry and the National Science Education Standards: A guide for teaching and learning, National Research Council, Washington, DC.

Oppenheimer, T. (2004) The flickering mind: saving education from the false promise of technology, Random House Trade Paperbacks, New York.

Richardson, V. (1996) 'The role of attitudes and beliefs in learning to teach', Handbook of Research on Teacher Education, vol. 2, pp. 102-119.

Riessman, C. K. (1993) Narrative analysis (Vol. 30). Sage Publ, Thousand Oaks, CA.

Sarason, S. (1982) The culture of the school and the problem of change, Allyn \& Bacon, Boston.

Schweingruber, H., Keller, T. \& Quinn, H. (2012) A Framework for K-12 Science Education: Practices, Crosscutting Concepts, and Core Ideas, National Academies Press, Washington, DC. 
Science for All Americans. (1989) A Project 2061 Report on Literacy Goals in Science, Mathematics, and Technology. Waldorf, MD.

Settlage, J., Odom, A. L. \& Pedersen, J. E. (2004) 'Uses of technology by science education professors: Comparisons with teachers' uses and the current versus desired technology knowledge gap', Contemporary Issues in Technology and Teacher Education [Online serial], 4(3). Available: http://www.citejournal.org/vol4/iss3/science/article2.cfm

Shulman, L. S. (1986) 'Those who understand: Knowledge growth in teaching', Educational Researcher, vol. 15, no. 2, pp. 4-14.

Southerland, S. A., Smith, L. K., Sowell, S. P. \& Kittleson, J. M. (2007) 'Resisting unlearning: Understanding science education's response to the United States's national accountability movement', Review of Research in Education, vol. 31, no. 1, pp. 45-77.

Waight, N. \& Abd-El-Khalick, F. (2011) 'From scientific practice to high school science classrooms: Transfer of scientific technologies and realizations of authentic inquiry', Journal of Research in Science Teaching, vol. 48, no. 1, pp. 37-70.

Waight, N., Chiu, M. \& Whitford, M. (2014) 'Factors that influence science teachers' selection and usage of technologies in high school science classrooms', Journal of Science Education and Technology, pp. 1-14, DOI 10.1007/s10956-014-9493-9.

Williams, M. \& Linn, M. C. (2000) 'WISE inquiry in fifth grade biology', Research in Science Education, vol. 32, no. 4, pp. 415-436.

Wertsch, J. V. (2002) 'Narratives as cultural tools in sociocultural analysis: official history in soviet and post-soviet Russia', Ethos, vol. 28, no. 4, pp. 511-533.

Windschitl, M. (2003) 'Inquiry projects in science teacher education: what can investigative experiences reveal about teacher thinking and eventual classroom practice'? Science education, vol. 87, no. 1, pp. 112-143. 